\title{
CITRUS ROOT DISTRIBUTION UNDER WATER STRESS GROWN IN SANDY SOIL OF CENTRAL FLORIDA
}

\section{JOSÉ ALVES JÚNIOR ${ }^{1}$, WIJE BANDARANAYAKE ${ }^{2}$, LARRY R. PARSONS ${ }^{2}$, ADÃO W. P. EVANGELISTA ${ }^{1}$}

\begin{abstract}
The experiment was conducted in an orchard located in University of Florida (Citrus Research and Education Center), Lake Alfred, Polk County, Florida, USA. The objective of this study was to evaluate the effects of water stress in root distribution of 'Valencia' orange tree on 'Swingle' citrumelo rootstock. Three treatments were imposed on the trees: 1) normal irrigation with microsprinklers, 2) no irrigation in winter (November through mid-March) and 3) rainfall exclusion by placing a water repelling fabric (Tyvek) under the trees. Trees in treatments 1 and 2 received normal rainfall during the winter, but treatment 3 received no rain. Normal irrigation was resumed on all treatments in mid March. Soil was collected using root auger head $(0.09 \mathrm{~m}$ diameter and height $0.25 \mathrm{~m}$ ) in two opposing quadrants (West and East at 3 horizontal distances from tree trunk $(1,2$ and $3 \mathrm{~m})$ and 4 depths $(0.0-0.15 ; 0.15-0.30 ; 0.30-0.60$ and $0.60-0.90 \mathrm{~m})$. The results from root sampling showed that there was a significant difference in root distribution between irrigated treatment and non irrigated/non rainfall.
\end{abstract}

KEYWORDS: irrigation, orange, roots.

\section{DISTRIBUIÇÂO DO SISTEMA RADICULAR DA CULTURA DO CÍTRUS SOB ESTRESSE HÍDRICO EM SOLO ARENOSO NA REGIÃO CENTRAL DA FLÓRIDA}

RESUMO: O experimento foi conduzido na Universidade da Flórida (Centro de Ensino e Pesquisa em Cítrus), em Lake Alfred, Polk County, Flórida-EUA. O objetivo deste estudo foi avaliar os efeitos do estresse hídrico na distribuição de raízes de laranjeira Valência enxertada em citrumelo Swingle, em um pomar de 11 anos de implantação. Três tratamentos foram aplicados: 1) plantas irrigadas por microaspersão no período seco (Nov-Mar); 2) plantas não irrigadas no período seco, e 3) plantas não irrigadas no período seco e também sem chuva no período úmido. As plantas do tratamento 3 não receberam chuva durante o período úmido, e os tratamentos 1 e 2 receberam chuva normalmente durantes 3 anos consecutivos (2003-2006). A irrigação normal foi recomeçada em todos os tratamentos, em meados de março. Amostras de raízes foram coletadas utilizando um trado de boca $(0,09 \mathrm{~m}$ de diâmetro e $0,25 \mathrm{~m}$ de altura) nos dois lados da linha de plantio, em 3 distâncias horizontais do tronco da planta $(1,2$ e $3 \mathrm{~m})$ e 4 profundidades $(0,0-0,15 ; 0,15-0,30 ; 0,3-0,60$ e $0,6-$ $0,9 \mathrm{~m})$. Os resultados mostraram que uma significante diferença na distribuição de raízes entre as plantas irrigadas e não irrigadas.

PALAVRAS-CHAVE: irrigação, laranja, raízes.

\section{INTRODUCTION}

Citrus root systems are important for tree anchorage and support. They also provide a mean of collection and transport of water and nutrients essential for tree growth and production. Studies of citrus root distribution in Florida have shown the potential for citrus to very deeply root and extensively under favorable environmental conditions. These studies showed that the depth of rooting was influenced by tree age, rootstock, soil type, and drainage characteristics. Irrigation

\footnotetext{
${ }^{1}$ Universidade Federal de Goiás. Escola de Agronomia e Engenharia de Alimentos, Campus Samambaia, CEP 74.690-000. Goiânia, GO, Brazil, jose.junior@ pesquisador.cnpq.br, awpego@bol.com.br.

${ }^{2}$ University of Florida, Institute of Food and Agricultural Sciences, Citrus Research and Education Center, 700. Experiment Station Road, 33850, Lake Alfred, Florida, EUA, lrparsons@crec.ifas.ufl.edu,wijeb@crec.ifas.ufl.edu. 
practices also affect citrus root system development and distribution. Soil water status is a major component of the root environment, affecting the growth and health of roots (BOMAN et al., 2002). For example, the highest concentration of fibrous roots develops under drip-irrigated systems within the volume of wetted soil around the emitters. Research conducted in Florida shows that soil water depletion is directly related to water availability and fibrous root abundance. The general pattern of water absorption by citrus trees suggests that water is depleted first in surface roots experiencing high soil water content. As the available water supply decreases in the surface soil there is an increase in absorption from roots at successively greater depths in advance of the drying front (NOLING, 2003).

The ideal environment for citrus roots is a porous, medium-textured, well-drained soil, where water is easily available but not in excess. When such soil is irrigated, water distribution itself throughout the soil profile in the root zone or drains away, leaving no excess. The growth and production of citrus may be impaired either by an excess of water in the root zone or by a lack of easily available water. A deficiency of water in the root zone produces detrimental effects on root growth. As the soil dry, root growth becomes slower and eventually ceases. However, if some of the roots are in soil containing easily available water, the roots in dry soil are not damaged. Roots do not grow through and ready to become active whenever the soil in which they exist receives moisture. Trees develop thicker feeder roots when repeatedly exposed to water stress. If soil conditions permit trees subjected to regular drought stress may develop deeper root systems than those under stress maintained with more abundant soil moisture conditions (BOMAN et al. 2002).

The root systems of citrus trees in deep, well-drained soils are 1.2 to $1.5 \mathrm{~m}$, with the main root system reaching only a depth of 0.6 to $0.9 \mathrm{~m}$. Studies have found roots on trees with rough lemon root-stock at a depth of $3.3 \mathrm{~m}$, while roots on sour orange trees have been found at a depth of $2.7 \mathrm{~m}$ in well-drained sandy Florida ridge soils. Water depletion studies confirmed that the roots were active at this depth but most of the water extraction came from the top $0.6 \mathrm{~m}$ (OBREZA \& BOMAN, 2002).

In general, citrus root growth is periodic during the months of February to early December with periods of inactivity occurring only during periods of shoot flush. During spring, summer, and fall, alternation of root and shoot growth has been repeatedly observed. The first root flush in Florida usually occurs between late February and early April. The timing of this is regulated by prevailing environmental conditions. The timing of the two remaining flushes is inconsistent, varying considerably between years and trees. However, distinct bursts of root growth frequently occur during the periods of May-June and again during August through October. It should be recognized that during the warm months, active periods of root growth can occur at any time in a series of smaller, reduced flushes or as major peaks of root growth activity (NOLING, 2003).

Under water deficiency, plant growth is readily inhibited and growth of roots is favored over that of leaves. When root water potential is suddenly reduced, osmotic adjustment occurs rapidly to allow partial turgor recovery and re-establishment of a potential gradient for water uptake. The loosening ability of the cell wall increases as indicated by a rapid decline in yield-threshold turgor. These adjustments permit roots to resume growth under low water potential (HSIAO \& XU, 2000).

The objectives of this study were to: i) evaluate the effects of water stress in root distribution of 'Valencia' orange tree on 'Swingle' citrumelo rootstock. Three treatments were imposed on the trees: 1) normal irrigation with microsprinklers, 2) no irrigation in winter (November through midMarch) and 3) rainfall exclusion by placing a water repelling fabric (Tyvek) under the trees. Trees in treatments 1 and 2 received normal rainfall during the winter, but treatment 3 received no rain. Normal irrigation was resumed on all treatments in mid March.

\section{MATERIAL AND METHODS}

Treatments were applied in the winter for three years (2003-2006) in a plot planted with 'Valencia' orange [Citrus sinensis (L.) Osbeck] on 'Swingle' [Poncirus trifoliata (L.) Raf. $\times$ Citrus 
paradisi Macf.] citrumelo rootstock. The trees were planted at a spacing of $7.5 \times 3 \mathrm{~m}$ and were 8 -yr old when treatments were started. Trees were irrigated with one $45 \mathrm{~L} \mathrm{~h}^{-1}$ microsprinkler per tree, with constant application pressure of $200 \mathrm{kPa}$, and with $0.2 \mathrm{~m}$ of distance from the trunk, wetting $4 \mathrm{~m}$ of diameter per tree (PARSONS \& MORGAN, 2004). The amount of water to be applied in each irrigation was estimated based on crop evapotranspiration, obtained at the weather station of the University of Florida, Citrus Research Education Center (CREC/IFAS).

The orchard was located in CREC/IFAS, Lake Alfred, Polk County, Florida, USA $\left(28^{\circ} 02^{\prime}\right.$ N, $\left.81^{\circ} 05^{\prime} \mathrm{W}\right)$. Average annual rainfall around $1300 \mathrm{~mm}$. The soil was an excessively drained Candler fine sand Hyperthermic, uncoated Lamellic Quartzipsamments. This soil has $>95 \%$ sand, <3\% clay, and $<1 \%$ organic matter in the top $2 \mathrm{~m}$. The bulk density of this soil is $\approx 1.6 \mathrm{Mg} \mathrm{m}^{-3}$ (Tab. 1) and water content at field capacity $(\theta \mathrm{fc})$ is $0.08 \mathrm{~m}^{3} \mathrm{~m}^{-3}$ (PARSONS \& BANDARANAYAKE, 2009, OBREZA et al., 1997), saturated hydraulic conductivity (Ks) is $150-1200 \mathrm{~mm} \mathrm{~h}^{-1}$ (OBREZA \& COLLINS, 2008).

TABLE 1. Physical properties of Ridge soil (Candler fine sand).

\begin{tabular}{|c|c|c|c|c|c|c|c|}
\hline Soil Profile & & Texture $^{*}$ & & ${ }^{ \pm}$Bulk & Porosity & ${ }^{ \pm}$Field Capacity & \\
\hline Depth & sand & Silt & clay & Density & & $\left(\theta_{\mathrm{v}}\right)$ & ${ }^{*} \mathrm{~K}_{\mathrm{s}}$ \\
\hline $\mathrm{Cm}$ & & $\%$ & & $\mathrm{~cm}^{3}$ & $\%$ & & $\mathrm{~cm} \mathrm{~h}^{-1}$ \\
\hline $0-15$ & 97.3 & 0.9 & 1.8 & 1.40 & 47 & 6.2 & 92.6 \\
\hline $16-30$ & 97.4 & 1.2 & 1.4 & 1.57 & 41 & 5.7 & \\
\hline $31-60$ & 97.4 & 1.2 & 1.4 & 1.54 & 42 & 5.1 & \\
\hline $61-90$ & 97.8 & 0.8 & 1.4 & 1.50 & 43 & 4.8 & \\
\hline$<90$ & 97.6 & 1.5 & 0.9 & 1.51 & 43 & 4.9 & \\
\hline
\end{tabular}

The orchard floor was kept clean during the experimental period. Ordinary pest control practices were performed and the fertilization was done as recommend by CREC/IFAS. The 'Valencia' grove is part of a project that was set up to evaluate the effect of water stress during winter season on yield. In the experimental plot, 9 trees which were similar in size were selected and divided into 3 groups. Each group was assigned to a different field condition. T1) irrigated during all year, T2) non-irrigated during winter and T3) no irrigation/no rainfall during winter time. Rainfall exclusion in treatment 3 was accomplished by placing a water excluding fabric (Tyvek) under the tree canopy. These treatments were imposed from the middle of November to the middle of March (mid fall to early spring). During the rest of the year, all treatments were irrigated equally. The roots under different irrigation levels were evaluated when the trees were 11 years old using the method explained by BÖHM (1979). The experimental design was a randomized block design with one tree as a replicate from each treatment ( 3 field conditions) in each one of the 3 blocks. Soil was collected using root auger head $(0.09 \mathrm{~m}$ diameter and height $0.25 \mathrm{~m})$ in two opposing quadrants, transverse of row trees (west and east at 3 horizontal distances from tree trunk (1,2 and $3 \mathrm{~m})$ and 4 depths $(0.0-0.15 ; 0.15-0.30 ; 0.30-0.60$ and $0.60-0.90 \mathrm{~m})$. Then, roots were removed and separated from soil with a $0.2-\mathrm{cm}$ mesh sieve into the following size classes: (i) fibrous roots $(<0.2 \mathrm{~cm}$ diameter) and (ii) woody roots $(0.2$ to $1.0 \mathrm{~cm}$ diameter). Samples were collected in the field and placed in sealed plastic bags to prevent water loss, then weighed. Later, the same material was washed in the laboratory and dried in an oven $\left(65^{\circ} \mathrm{C} ; 72 \mathrm{~h}\right)$ for dry mass determination. Root length was determined by counting the number of horizontal and vertical intersections of roots in a grid system of $1.0 \times 1.0 \mathrm{~cm}$ (Tennant, 1975), which multiplied by 11/14 and divided by the volume of the corer gives the root density in $\mathrm{cm} \mathrm{cm}^{-3}$ soil. A simple analysis of variance was used to test the hypothesis that means from root distribution were equal using the Statistical Analysis Systems (SAS) GLM Procedure, to 0.10 level of probability. 


\section{RESULTS AND DISCUSSION}

The results had a significant difference $(\mathrm{P}<0.10)$ in root distribution between irrigated treatment (T1) and non irrigated/non rainfall treatment (T3) when compared with the root distribution (feeder roots $<0.2 \mathrm{~cm}$ ) in the horizontal direction (Table 2, Figure 1). The root distribution in non irrigated treatment (T2) was intermediate. At a $2 \mathrm{~m}$ horizontal distance from the trunk, treatment T3 $\left(0.5 \mathrm{~cm} \mathrm{~cm}^{-3}\right)$ had greater root length density than $\mathrm{T} 1\left(0.26 \mathrm{~cm} \mathrm{~cm}^{-3}\right)$. This was probably due to the characteristic of citrus trees develop thicker feeder roots when repeatedly exposed to water stress, as related by BOMAN et al. (2002).

The results had not a significant difference in root distribution between treatments to roots of 0.2 to $1.0 \mathrm{~cm}$ of diameter.

TABLE 2. Length density of feeder roots $(<0.2 \mathrm{~cm}$ diameter) of 'Swingle' citrumelo trees (11 years old) distributed horizontally and depth in a soil profile under 3 different field condition: Irrigated by microsprinkler (T1), non irrigated (T2) and non irrigation + non rainfall during winter time (T3).

\begin{tabular}{|c|c|c|c|c|c|c|c|}
\hline & \multicolumn{7}{|c|}{ Length density Roots $\left(\mathrm{cm} \mathrm{cm}^{-3}\right)(<0.2 \mathrm{~cm}$ diameter $)$} \\
\hline & \multicolumn{3}{|c|}{ Horizontal distance from the trunk (m) } & \multicolumn{4}{|c|}{ Depth (m) } \\
\hline & 1 & 2 & 3 & $0.0-0.15$ & $0.15-0.3$ & $0.3-0.6$ & $0.6-0.9$ \\
\hline $\mathrm{T} 1$ & $1.045 \mathrm{a}$ & $0.262 \mathrm{~b}$ & $0.211 \mathrm{a}$ & $0.994 \mathrm{a}$ & $0.364 \mathrm{a}$ & $0.036 \mathrm{a}$ & $0.124 \mathrm{a}$ \\
\hline $\mathrm{T} 2$ & $0.876 \mathrm{a}$ & $0.437 \mathrm{ab}$ & $0.246 \mathrm{a}$ & $1.232 \mathrm{a}$ & $0.148 \mathrm{~b}$ & $0.038 \mathrm{a}$ & $0.140 \mathrm{a}$ \\
\hline $\mathrm{T} 3$ & $0.933 \mathrm{a}$ & $0.499 \mathrm{a}$ & $0.145 \mathrm{a}$ & $1.236 \mathrm{a}$ & $0.183 \mathrm{ab}$ & $0.032 \mathrm{a}$ & $0.125 \mathrm{a}$ \\
\hline LSD & 0.4118 & 0.2168 & 0.2643 & 0.2854 & 0.2071 & 0.0186 & 0.146 \\
\hline \multirow[t]{4}{*}{$\mathrm{CV} \%$} & 27.28 & 34.20 & 83.15 & 15.58 & 56.25 & 33.19 & 70.96 \\
\hline & \multicolumn{7}{|c|}{ Length density Roots $\left(\mathrm{cm} \mathrm{cm}^{-3}\right)(0.2$ to $1.0 \mathrm{~cm}$ diameter $)$} \\
\hline & \multicolumn{3}{|c|}{ Horizontal distance from the trunk (m) } & \multicolumn{4}{|c|}{ Depth (m) } \\
\hline & 1 & 2 & 3 & $0.0-0.15$ & $0.15-0.3$ & $0.3-0.6$ & $0.6-0.9$ \\
\hline $\mathrm{T} 1$ & $0.072 \mathrm{~ns}$ & $0.000 \mathrm{~ns}$ & $0.000 \mathrm{~ns}$ & $0.030 \mathrm{~ns}$ & $0.037 \mathrm{~ns}$ & $0.000 \mathrm{~ns}$ & $0.005 \mathrm{~ns}$ \\
\hline $\mathrm{T} 2$ & $0.046 \mathrm{~ns}$ & $0.003 \mathrm{~ns}$ & $0.005 \mathrm{~ns}$ & $0.041 \mathrm{~ns}$ & $0.012 \mathrm{~ns}$ & $0.000 \mathrm{~ns}$ & $0.001 \mathrm{~ns}$ \\
\hline $\mathrm{T} 3$ & $0.036 \mathrm{~ns}$ & $0.014 \mathrm{~ns}$ & $0.006 \mathrm{~ns}$ & $0.040 \mathrm{~ns}$ & $0.000 \mathrm{~ns}$ & $0.000 \mathrm{~ns}$ & $0.016 \mathrm{~ns}$ \\
\hline
\end{tabular}

*: Means in each column followed by the same letter do not differ statistically at the 0.10 level by Tukey Test; CV = Variation coefficient; LSD = Least Significant Difference.

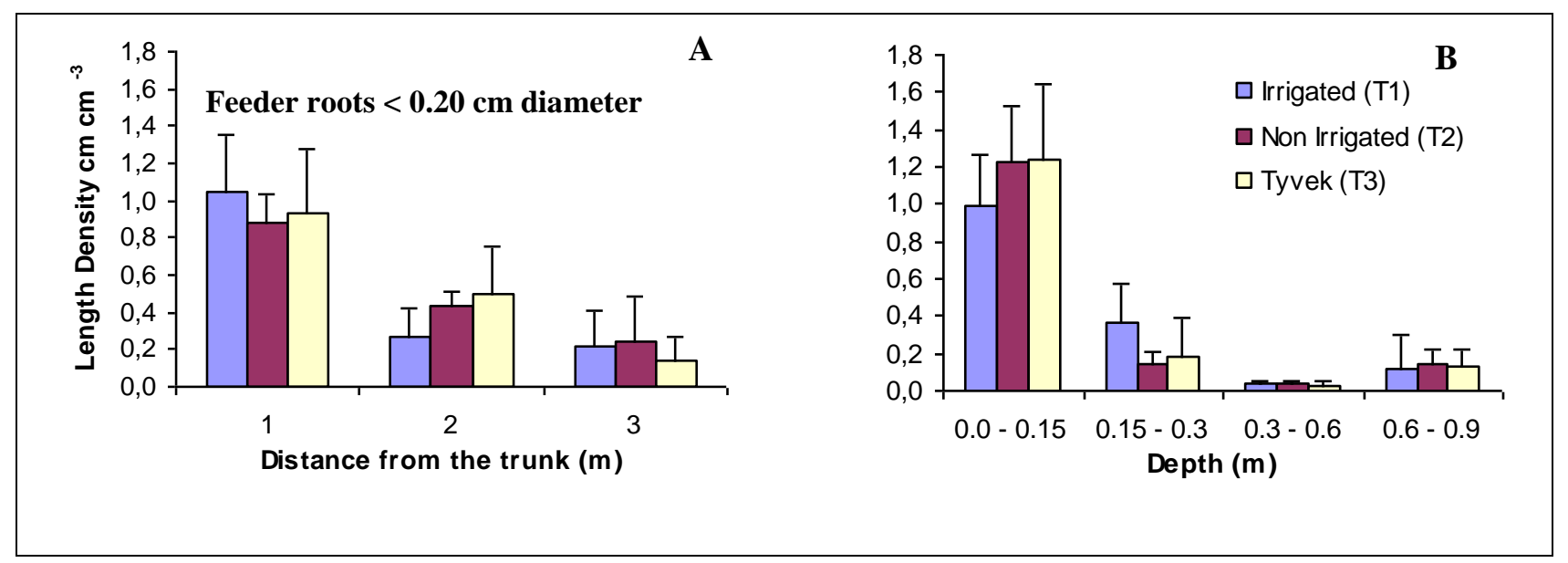

FIGURE 1. Length density of feeder roots $(<0.2 \mathrm{~cm})$ of 'Swingle' citrumelo trees (11 years old) distributed horizontally (A) and depth (B) in a soil profile under 3 different treatments: Irrigated by microsprinkler (T1); non irrigated (T2); and non irrigation/ non rainfall during winter time (T3). 
There was a significant difference $(\mathrm{P}<0.10)$ in root distribution between $\mathrm{T} 1$ and $\mathrm{T} 2$ when compared in depth. The root distribution in T3 was intermediate. In the soil layer of $0.15-0.30 \mathrm{~m}$ greater amounts of fine roots were found in the profiles of microsprinkler irrigated trees that indicated higher root activity in those profiles compared to the non-irrigated. In this layer, T1 (0.36 $\left.\mathrm{cm} \mathrm{cm}^{-3}\right)$ had the double of length density roots than T2 $\left(0.18 \mathrm{~cm} \mathrm{~cm}^{-3}\right)$ and T3 $\left(0.15 \mathrm{~cm} \mathrm{~cm}^{-3}\right)$. This is in concordance with COELHO et al. (2002) which found that root system of microsprinkler irrigated trees occupied greater volume in the soil compared to the one under water stress conditions.

For all evaluated trees, in average the $0.0-0.3 \mathrm{~m}$ soil layer had the larger percentage of roots and until $2 \mathrm{~m}$ horizontal distance from the trunk.

Other studies also related about root citrus distribution in irrigated area. COELHO et al. (2002) evaluated root distribution of orange cv. Pêra under non-irrigated and under microsprinkler irrigated conditions in a Coastal Plain Sandy Soil (Brazil). Root samples were collected by monolith method from trenches, which were dug aside, the plant trunk at longitudinal and orthogonal directions to plant rows. Results showed that root system of microsprinkler irrigated trees occupied larger volume in the soil compared to the one under non-irrigated conditions. Higher amounts of fine roots were found in the profiles of microsprinkler irrigated trees that indicated greater root activity in those profiles compared to the non-irrigated ones. It can be observed that the most suitable locations for soil water sensor placement in orange orchards using microsprinkler irrigation are between 0 and $2.5 \mathrm{~m}$ of radial distance from the trunk, at depths between 0 and $1.0 \mathrm{~m}$. Therefore, the same irrigation system used in this current research was differentially influence, probably due to differences in soil and rootstock.

ALVES JR. et al. (2004) evaluated the root system distribution of young 'Tahiti' (Citrus latifolia Tan) acid lime irrigated by drip system under field conditions in Brazil. The experiment consisted of five levels of irrigation $(0 \%, 25 \%, 50 \%, 75 \%$ and $100 \%$ of crop evapotranspiration measured by a weighing lysimeter) and two depths $(0.0,0-0.3$ and $0.3-0.6 \mathrm{~m})$ as well as four horizontal sample points $(0.3 ; 0.6 ; 0.9$ and $1.2 \mathrm{~m}$ of distance from trunk). The analysis was carried out in a 30-month-old orchard and 17 months after the beginning of irrigation levels. The results showed that there were no differences in root distribution as to depths, most of them at $0.0-0.3 \mathrm{~m}$. However, the horizontal distribution was bigger at lower levels $(0,25$ and $50 \%)$ than in the highest levels (75 and $100 \%)$. In the latter, root concentration reached up to $0.6 \mathrm{~m}$, indicating that water stress induced the root growth horizontally. Similar results were obtained when compared with the present research. Even though researches has been conducted with different irrigation systems, different climate, soil and tree ages. The roots distribution was similar probably because both used same rootstock.

TESTEZLAF et al. (2007) evaluated root distribution of 36 years old 'Valência' oranges trees with Citrus limonia Osbeck rootstock, under traveler gun irrigation, in Typic Hapludox in Brazil. Soil samples were taken from five trees in two orthogonal radii, one in the direction of the crop rows and the other in between rows, at $0.6 \mathrm{~m}$ depth. The root system distribution was determined by dry weight of the roots with diameters equal or less than $1.5 \mathrm{~mm}$. The $0.0-0.4 \mathrm{~m}$ soil layer showed the larger percentage of root, with reduction of root concentration from the end of the tree canopy to between rows.

There was no significant difference in root length density among either horizontally or with depth. This was probably because the irrigation treatments in the current study were only applied during the fall and winter (November - March). The least active period of root growth is during the winter. NOLING (2003) related that although the first root flush in Florida usually occurs between late February and early April, the most active period of root growth occurs during the spring (MayJune) and summer (August-October).

Plants maintained with adequate soil moisture condition have great growth (SOUSA et al. 2006). During the first several years after planting, there is generally a good relationship between 
increased irrigation and increase in canopy volume and orange yield in Florida (PARSONS et al., 2001). The soil water distribution has an important effect in soil roots distribution under trickle irrigation (CLOTHIER \& GREEN, 1994; CLAUSNITZER \& HOPMANS, 1994; and COELHO \& OR, 1996). Water shortages typically decrease growth of citrus tree, and some studies showed that water stress reduce mainly growth of canopy and fruits (Levy et al., 1978). MARLER \& DAVIES (1990) compared growth of 'Hamilin' trees with 1 year old, under 20; 45 and 65\% of soil water, and observed decrease of roots and canopy growth in citrus trees under $65 \%$.

SANTOS, et al. (2005) in Brazil characterized water uptake by 'Tahiti' lemon (Citrus latifolia Tanaka) roots in the soil profile under different microsprinkler irrigation intervals. The work was conducted under semi-arid conditions, in a sandy loam soil. Water uptake by roots was determined from soil water content by means of TDR probes, at several positions in the soil profile between two irrigation events. The root distribution was evaluated based upon data of length and root diameter at the same locations of TDR probes. According to the results, it was verified that: water uptake reduced as the distance root-microsprinkler increased; lemon crop extracts more water when there is no restriction to the available water in the wetted volume; the area of water uptake by lemon roots increases with increase in the irrigation intervals; roots with diameter between 0.5 and $2.0 \mathrm{~mm}$ extracted more water from the soil.

\section{CONCLUSION}

There were effects of water stress in root distribution of 'Valencia' orange tree on 'Swingle' citrumelo rootstock between irrigated treatment and non irrigated/non rainfall.

The horizontal distribution of thicker feeder roots was higher in non-irrigated/non rainfall orange trees during winter time than irrigated trees, indicating that water stress induced the root growth horizontally.

Root system of microsprinkler irrigated trees occupied higher volume in the soil compared to the one under water stress conditions, indicating higher root activity in wet area.

For all evaluated trees, in average the $0.0-0.3 \mathrm{~m}$ soil layer showed the larger percentage of roots and until $2 \mathrm{~m}$ horizontal distance from the trunk.

\section{REFERENCES}

ALVA, A.K.; PRAKASH, O.; FARES, A.; HORNSBY, A. G. Distribution of rainfall and soil moisture content under citrus tree canopy and at the drip line. Irrigation Science. v.18, p. 556-562. 1999.

ALVES JR., J.; LOURENÇÃO, M. S.; SILVA, T. J. A.; SILVA, C. R.; FOLEGATTI, M. V. Root system distribution of young 'Tahiti' acid lime trees under different levels of irrigation. Irriga, Botucatu, v. 9, n.1, p. 270-281, 2004.

BOMAN, B.; PARSONS, L. R. Evapotranspiration. In: BOMAN, B. Water and Florida Citrus: use, regulation, irrigation, systems, and management. SP281. Gainesville: Institute of Food and agricultural Sciences - University of Florida. 2002. p. 163-174.

BÖHM, W. Methods of studying root systems. In: W.D.(Ed.) Ecological studies 33. Heidelberg: Springer-Verlag Berlin, 1979. 189 p.

CLAUSNITZER, V.; HOPMANS, J.W. Simultaneous modeling of transient three-dimensional root growth and soil water flow. Plant and Soil, Dordrecht, v. 164, n. 2, p. 299-314, 1994.

CLOTHIER, B.E.; GREEN, S.R. Root zone processes and the efficient use of irrigation water. Agricultural Water Management, Amsterdam, v. 25, n. 1, p. 1-12, 1994.

COELHO, E. F.; OR, D. A parametric model for two-dimensional water uptake by corn roots under drip irrigation. Soil Science Society of America Journal, Madison, v. 60, n. 4, p. 1039-1049, 1996. 
COELHO, E. F.; OLIVEIRA, F. DAS C.; ARAUJO, E. C. E.; VASCONCELOS, L. F. L. Root distribution of "Pêra" orange trees under non-irrigated and irrigated conditions in a sandy soil. Pesquisa Agropecuária Brasileira, Brasília, v. 37, p. 603-611. 2002.

HSIAO, T.C.; XU, L.K. Sensitivity of growth of roots versus leaves to water stress: biophysical analysis and relation to water transport. Journal of Experimental Botany, Oxford, v. 51, p.1595-1616, 2000.

LEVY, Y.; BIELORAI, H.; SHALHEVET, J. Long-term effects of different irrigation regimes on grapefruit tree development and yield. Journal of the American Society for Horticultural Science, Alexandria, v. 103, n. 5, p. 680-3, 1978.

MARLER, T. E.; DAVIES, F. Microsprinkler irrigation and growth of young 'Hamilin' orange trees. Journal of the American Society for Horticultural Science, Alexandria, v. 115, n. 1, p. 45-51, 1990.

NOLING, J. W. Citrus root growth and soil pest management practices. Gainesville: University of Florida, 2003. 6p. (IFAS Extension), Disponível em: <http://edis.ifas.ufl.edu/ENY617>.

OBREZA, T. A., BOMAN, B. J. Soil and water relationships. In:_ B. J. Boman (ed.) Water and Florida citrus. SP 281, Univ. of Florida-IFAS, Gainesville, FL. p. 132-147, 2002.

OBREZA, T. A. AND COLLINS, M. E. Common Soils Used for Citrus Production in Florida. SL 193: Florida Cooperative Extension Service, IFAS/ University of Florida. 12 p. 2008.

http://edis.ifas.ufl.edu/pdffiles/SS/SS40300.pdf

OBREZA, T. A., PITTS, D. J., PARSONS, L. R., WHEATON, T. A. AND MORGAN, K. T. Soil water-holding characteristic affects citrus irrigation scheduling strategy. Proc. Fla. State Hort.Soc. v.110, p. 36-39, 1997.

PARSONS, L. R.; MORGAN, K. T.; WHEATON, T. A.; CASTLE, W. S. High application rates of reclaimed water benefit citrus tree growth and fruit production. HortScience, St. Joseph, v. 36, n. 1, p. 1273-1277, 2001.

PARSONS, L. R., MORGAN, K. T. Management of microsprinkler systems for Florida citrus. Gainesville: University of Florida, 2004. 4p. (IFAS Extension). Disponível em:

$<$ http://edis.ifas.ufl.edu/HS204>.

PARSONS, L. R. AND BANDARANAYAKE, W. M. Performance of a New Capacitance Soil Moisture Probe in a Sandy Soil. Soil Science Society of America Journal, Madison, v. 73, n. 4, p.1378-1385, 2009.

SANTOS, D. B.; COELHO, E. F.; AZEVEDO, C. A. V. de. Water uptake by lemon roots under different irrigation frequencies. Revista Brasileira de Engenharia Agrícola e Ambiental, Campina Grande, v. 9, p. 327-333, 2005.

SOUSA, V. F.; FOLEGATTI, M. V.; FRIZZONE, J. A.; CORREA, R. A. L.; VIANA, T. V. A. Soil moisture in the root zone of passion fruit tilled under drip irrigation. Engenharia Agrícola, Jaboticabal, v. 26, n. 2, p. 365-373, 2006.

TENNANT, D. Atest of amodified line intersect method of estimating root length. The Journal of Ecology, Oxford, v. 63, p. 995-1001. 1975.

TESTEZLAF, R.; COLETTI, C.; MATSURA, E. E. Root distribution of 'Valência' orange under traveler gun irrigation. Pesquisa Agropecuária Brasileira, Brasília, v. 42, n. 6, p. 905-908, 2007.

ZEKRI,L M.; PARSONS, L. R.. Determination of field capacity in a Florida sandy soil and drainage times at different depths. HortTechnology, Alexandria, n.2, apr./jun. 1999. 